\title{
The Revitalization of The Historic Centre of The Town Slany
}

\author{
PEŠKOVÁ Zuzana ${ }^{1, a^{*}}$ \\ ${ }^{1}$ Faculty of Civil Engineering, CTU in Prague, Thakurova 7/2077, 16629 Prague 6 - Dejvice, \\ Czech Republic \\ azuzana.peskova@fsv.cvut.cz
}

Keywords: revitalization, historic centre, bridge, Slany, Vinarickeho Street, U Brodu.

\begin{abstract}
.
In 2006, the town council of Slany decided to respond to the new trend of regional policy in the Central Bohemia region and focused on the revitalization of the historic core of the town. The largescale project was assigned to a team of professionals (teachers and graduates of the Faculty of Civil Engineering of the Czech Technical University in Prague), led by Professor Sykora. Team members are to deal with issues of historical centre. The project presented a challenge to test theory, principles and procedures in practical design. The projected area featured Masaryk Square and 22 adjacent streets defined by the existing town walls. The reconstruction project of Vinarickeho Street was the first part of the overall project of revitalization of the historic core of the town chosen to implement. This reconstruction was one of the most technically, organizationally and financially complex works that have been undertaken in Slany recently. Construction started in November 2010 and lasted one year. Although this is a project of smaller scope, thanks to its complexity, sensitive approach and craftsmanship it brought the creators the price Construction of the Year 2012 in the Central Bohemia region and advanced to the second round in the competition Construction of the Year 2012 in Czech Republic.
\end{abstract}

\section{Introduction}

The royal town Slany is a town in the Kladno district about $29 \mathrm{~km}$ northwest of Prague; inhabited by over 15,000 people in 1,927 houses and has a population density of 499 inhab. / $\mathrm{Km}^{2}$ [1].

Slany was established as the seat either of salt-makers or in relation to the documented trade route. The first recorded mention of the town is from 1239, and it is clear that the settlement called today $U$ Brodu by monks from Ostrov is much older. Slany was elevated to town status sometime between the years 1295 to 1305 , during the reign of King Wenceslas II. The transformation to a royal town was a single local act. In terms of urban planning, the new location was influenced by the older developed agglomeration. The newly built town covered a peak position on the hill northwest from the church of St. Gothard. The main longitudinal axis of the town remained the Saxon Way (Vinarickeho, Husova Street). A large rectangular square was located eccentrically in the northeastern sector of the newly built town. The main route passed on the south side of the square; the houses on the north side were adjoined with the town walls. Construction of the town wall started in parallel with the location of the town. The main gates at the entrance to the town were on Lounska (in the west) and on Prague (in the east). The Velvarska gate in the north formed part of the square. The fourth gate in the southern part of the town called Fortenska or Vsehlusska was constructed later. The intention to establish a new town on checkerboard urban plan, typical for medieval urban locations, was deformed both morphologically and also incorporating existing church of St. Gothard with the provost of the Benedictines to the circuit of the town. The original Romanesque church was replaced by the architecturally challenging Gothic church in the mid-14th century. In 1371 a fire practically burnt the whole town down to ashes. Since then, the town has used stone construction to build the city. During the Hussite wars, Slany supported the people of Prague and subsequently was conquered by the Taborites. After the defeating Taborites the town yielded to the government. King George of Podebrady gave the town many privileges. During the Thirty Years War, the whole town 
was devastated. Until 1960, Slany was a separate district which then in that year, it was incorporated into the Kladno district. In 1992 the historical core of the town became an urban heritage zone [1].

In 2006, the town council decided to respond to the new trend of regional policy in the Central Bohemia region and focused on the revitalization of the historic core of the town.

The large-scale project was assigned to a team of professionals (teachers and graduates of the Faculty of Civil Engineering of the Czech Technical University in Prague), led by Professor Sykora. Team members are to deal with issues of historical core. The project presented a challenge to test theory, principles and procedures in practical design. The projected area featured Masaryk Square and 22 adjacent streets defined by the existing town walls. Work began in June 2006. In October 2006, surveys were completed and partial architectural designs began: Soukenicka Street (November 2006), Vinarickeho (December 2006), Masaryk Square (August 2007), Husova (November 2007), streets of the southern part of the town (in December 2007), streets of the nothern part of the town (February 2008) and streets of the eastern part of the town (February 2008). During 2008, a construction project for the revitalization of the historic core of the town was prepared. Regional policy preferences have changed and health care projects became the priority in funding. Due to these circumstances, this ambitious project of revitalization disintegrated into parts. In $2009-2010$ the reconstruction project of Vinarickeho Street was modified.

Architectural - engineering design of the revitalization of the lower part of Vinarickeho, based on extensive studies, contains:

- construction of new engineering networks that had to be built in a very small space in the original medieval street and had to be placed between the existing utilities and fragments of historical masonry in the underground,

- $\quad$ substitution of a damaged road ramp by new retaining walls, design of the neoplasm was inspired by a drawing of Josef Willenberg from the 18th century,

- substitution of the original surface parterre with new tiles, which expresses their function in space and at the same time remind the existence of historic building bridge, Barbican and the Prague Gate,

- location sculptural decoration in the foreground of the bridge, which forms the artistic accent of the whole composition,

- layout of the adjacent terrain to resemble the original castle moat.

This reconstruction was one of the most technically, organizationally and financially complex works that have been undertaken in Slany recently. Thanks to the concerted efforts of architects and civil engineers; a construction that includes both engineering modifications, and historical remarks was implemented, thus the town gained a revitalization of an entirely new dimension.

The construction site is situated on the medieval road from Prague to Saxony. At the beginning of the 13th century, during the reign of King Wenceslas II., the town walls were built here. Between 1460 and 1472 King George of Podebrady solidified the town walls and added massive walls with gates. A Gothic-Renaissance one-arch bridge, made of massive carved sandstone blocks was built for easier entrance to the Prague Gate at the foot of the towering walls of the Barbican [2]. In modern history all utilities including sewers, conduits, and aqueducts were inserted into the bridge and eventually a reinforced concrete girder bridge (ramp) was installed.

Vinarickeho Street is the main access road to the centre of the town with two-way traffic from the ramp below the church of St. Gothard almost to Masaryk Square, where, due to narrowing of the street space for the roadway changes to one-way traffic. The original solution of the transport outlet Vinarickeho to $U$ Brodu led through a modern, but technically impaired reinforced concrete ramp, covering up the original stone arch bridge in front of house 163 and in front of a portion the preserved town walls. The street ground plan is defined by the medieval land allotment. Its width is $12-14 \mathrm{~m}$ on average and the longitudinal height is $65 \mathrm{~cm}$ to $190 \mathrm{~m}$ length. Sidewalks were relatively narrow and the basalt mosaic roadway was mostly asphalt, supplemented by pavement of large original granite block. South of the ramps is an artificial reservoir with stone riverside walls and lawn. Overall, the entrance space to the historic centre was unsightly [3]. 


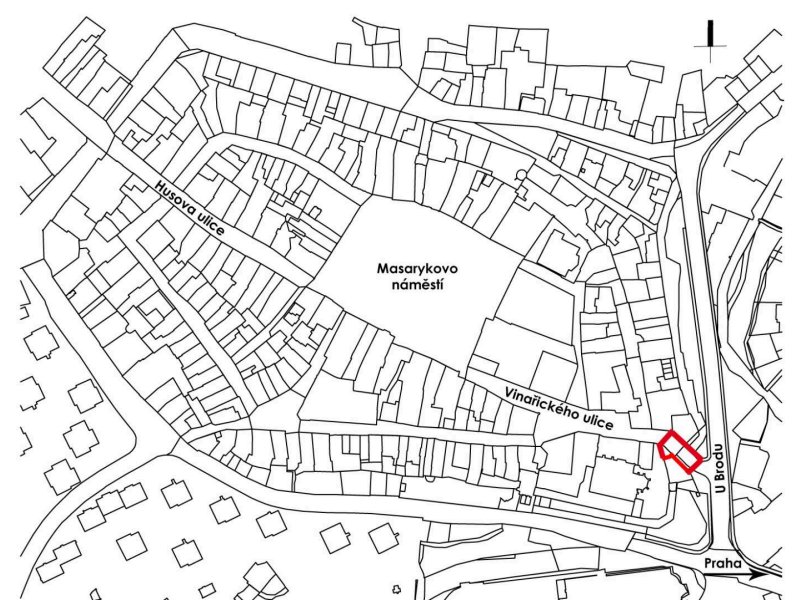

Fig. 1 - Slany situation with highlighted construction site of the bridge (author, 2011)

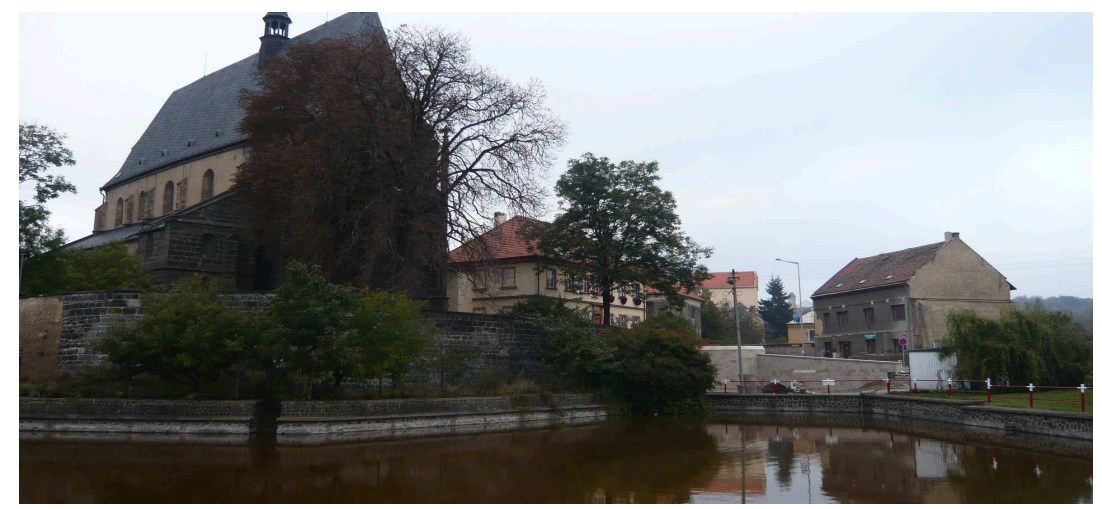

Fig. 2 - Panorama of the entrance to town with still unfinished bridge $U$ Brodu (photo author, 2011)

\section{Architectural Design}

Architectural design is based on the total philosophy of regeneration of the historic core of the town by the prof. Sykora's architects team: more pleasant public spaces, prioritizing pedestrians before motor transport, the precise definition of the functional surfaces of roads (traffic lanes, reserved parking, sidewalks, driveways and garages in the yards of houses) and the need to repair the damaged facades and the completion of the space with urban furniture. The design of the area under the walls is based on the idea to remind one of its historical appearance - an original one arched stone bridge over a stream with the Prague Gate [3].

The final architectural form of the bridge went through a long process of fulfilling this concept. The first architectural study was prepared in 2006 [3]. Since then, the design was modified, simplified and clarified several times in its detail. The final design reflected consultations with experts from the National Heritage Institute, and the results of archaeological research conducted during the construction of the bridge. Among the first architectural studies and projections of the bridge took five years. The time was important in this case. The architectural design could ripen into its final form, which is persuasive, no frills and reminds of the actual historical details of the place.

The one - arch - bridge structure with pillars is a concrete construction with tiles of sandstone from Bozanov. In the foreground of the bridge is a statue of St. Anthony of Padua, which was picked from the depository of the National Museum and placed on a new pedestal with Baroque inspired detail. Under the bridge, a dry moat was built. Unfortunately, funds and identified terrain conditions have not yet permitted to extend the water level under the bridge arch.

Design adjustments were projected to keep the main road into the town centre. The street layout has been maintained, expanded sidewalks and adjusted the roadway, which is vertically separated from the sidewalk with the curb stone. The original paving on the road was restored which consisted of large blocks of dark gray granite, and on the sidewalks a mosaic of granite countertops and basalt 
paving was applied. To commemorate the archaeological finds (Prague Gate, bridge and Barbican) the paving was created from irregular quarried yellow granite in the original ground plan of the historical construction. To commemorate the original bridge arch, yellow granite sheet pile pavement was made. The edges of the sidewalks are lined by stone curbs of pale granite.

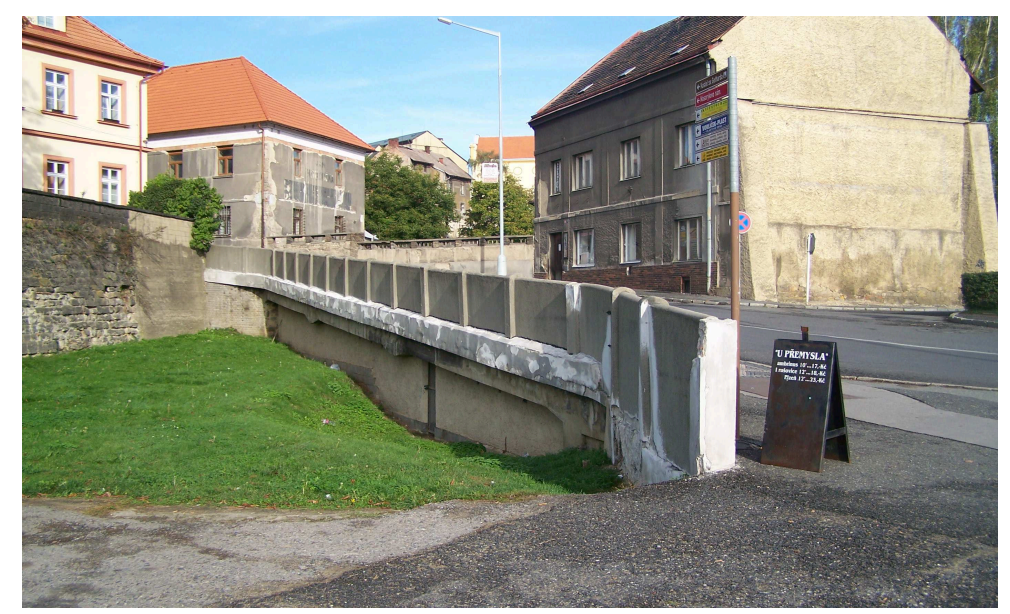

Fig. 3 - Original concrete ramp as the main entrance to the historical centre of town Slany (photo Jiri Novotny, 2006)

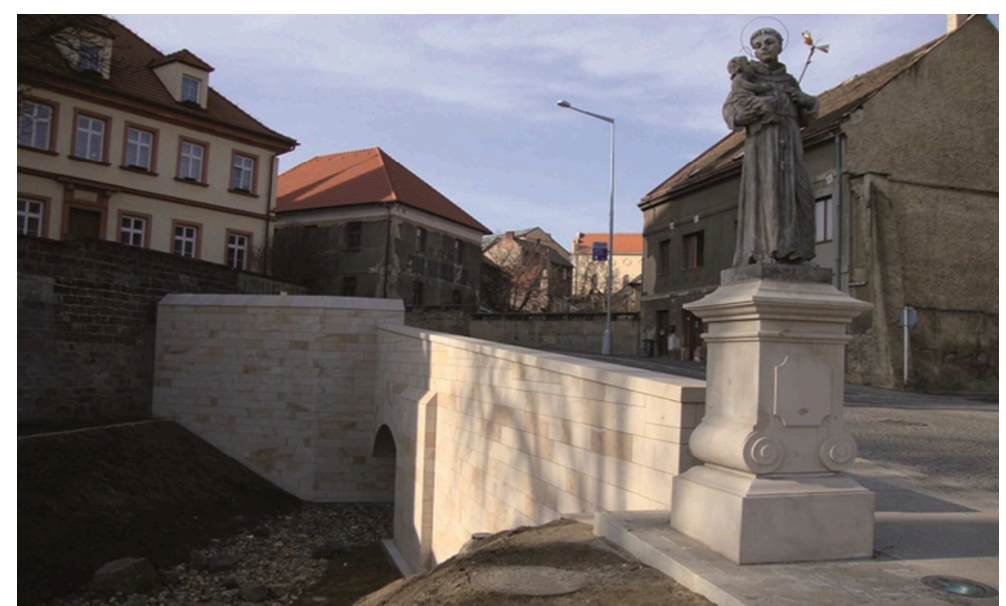

Fig. 4 - Revitalization of Bridge $U$ Brodu, the lower part of the Vinarickeho Street (photo Jan Mrzilek, 2012)

\section{Bridge}

The construction site is from a historical and constructional perspective diverse, earlyconstruction activities date back to the Middle - Ages. The original one - arch stone bridge leading to the former Prague Gate is in this space. Furthermore, in the past, in the area of the original stone bridge utility lines were installed; notably sewer lines, water mains, gas, electrical power cables, street lighting. From the above utilities the original stone arch bridge was most affected by the sewer construction, which the original space under the arch was divided into two parts by a wall supporting an ovate concrete sewer. Another visible violation was the implementation of tap water, which passes through the top of the arch and is clearly visible from the space under the arch. The most obvious intervention was the construction of a reinforced concrete girder bridge structure, which continued to the original bridge wall. In terms of the use, both bridge structures were unsuitable [4].

Method of construction:

- excavation of the area between the arch, the bastion and banks (area of the dry creek) to ensure access, 
- demolition of the non-bearing side walls for access to the space under the bridge,

- static protection of the existing slatted structure of the bridge,

- removal of the roadway and sidewalk from top up to the concrete bridge structure,

- demolition of the slatted structure for securing access to perform work on the arch bridge,

- implementation of supporting walls of the bastion and supporting wall in front of the arch, construction of the supporting walls are outside the supporting structure of the existing reinforced concrete bridge,

- demolition of the remaining part of the bridge except for the conduit routes,

- backfilling and stabilization of the hollow spaces of the original bridge (mainly around the arc and the bastion in coordination with the construction of water supply and sewage),

- stone siding of the bridge,

- installation of street lighting and relocation of radio,

- drainage of the dry creek (the construction of sewer B),

- resurfacing the road and pavement on the bridge,

- landscaping in the area of the dry stream, dams and space along the town walls [4].

The name "bridge" in case of this construction does not reflect the exact character of the construction it is rather a visual illusion of a bridge, because the supporting structure is not a continuous free space. The supporting structure is arched above the illusion of a dry creek.

The bridge construction consists of a reinforced concrete vault, stored on the walls. The arch span is a $5.50 \mathrm{~m}$ span relative to the centre line of the supporting structure and is $6.70 \mathrm{~m}$. The width of the space under the bridge is $3.00 \mathrm{~m}$. The roadway and sidewalks on the bridge are kept at a distinct longitudinal gradient of $7.9 \%$. At the bottom of the bridge (towards the centre) there is a parallel wing protruding from the supporting structure and the length is $3.00 \mathrm{~m}$. A separate dilated angular retaining wall continues from this wing. On the upper edge the bridge (towards the town) follows on bench angled abutment arch second supporting wall that has the structural character of slant bridge wings. The aesthetic appearance creates the idea of a bastion. The supporting structure is a reinforced concrete frame with compact interconnected contact between the walls and vault. All visible elements are made of stone block masonry (block height is about $25 \mathrm{~cm}$ ). The vault in the view is vaulted with stone pie - shaped segments. The masonry is anchored with reinforcements embedded in the masonry joints and embedded in the concrete elements. The foundations are shallow on clay soil. The construction is founded above the water table. Pseudo - horizontal (nearly horizontal) reverse surfaces of the support construction (arches) are protected against the effects of moisture and a defrosting solution was sprayed on the entire surface. Insulation protects against damage to the protective layer of the concrete. A classic design with protection made from mastic asphalt was not installed in view of the considerable longitudinal inclination. Vertical reverse surfaces of the supports are insulated with a double epoxy-asphalt coating protected by a suspended drainage mattress Enkadrain. The soil on the reverse of the abutments is drained by drainage mats connected to a drainage pipe that leads through the wall with a pipe above the water level in the pond. In the longitudinal direction, the bridge haunches are adapted for the construction of the road, in the character of a transition plate. In the transverse direction of the bridge is a transition wedge of designed plain concrete. The paved roadway on the bridge and around the bridge in the transition area is not dilated, for a small bridge span. Railings on the bridge are made of stone, at a height 100 $\mathrm{cm}$ above the sidewalk, railing standard thickness is $50 \mathrm{~cm}$. The railings are finished with stone slabs. An atypical solution of the railing above the upper pillar is in the pavements of the special railing adjacent of the bastion follow-up on the railing retaining walls. Lighting the bridge is solved by lights placed in the railing of the bridge [4].

Materials: concrete C 30/37 XF2, concrete reinforcement R 10 505, stone facing - sandstone. 


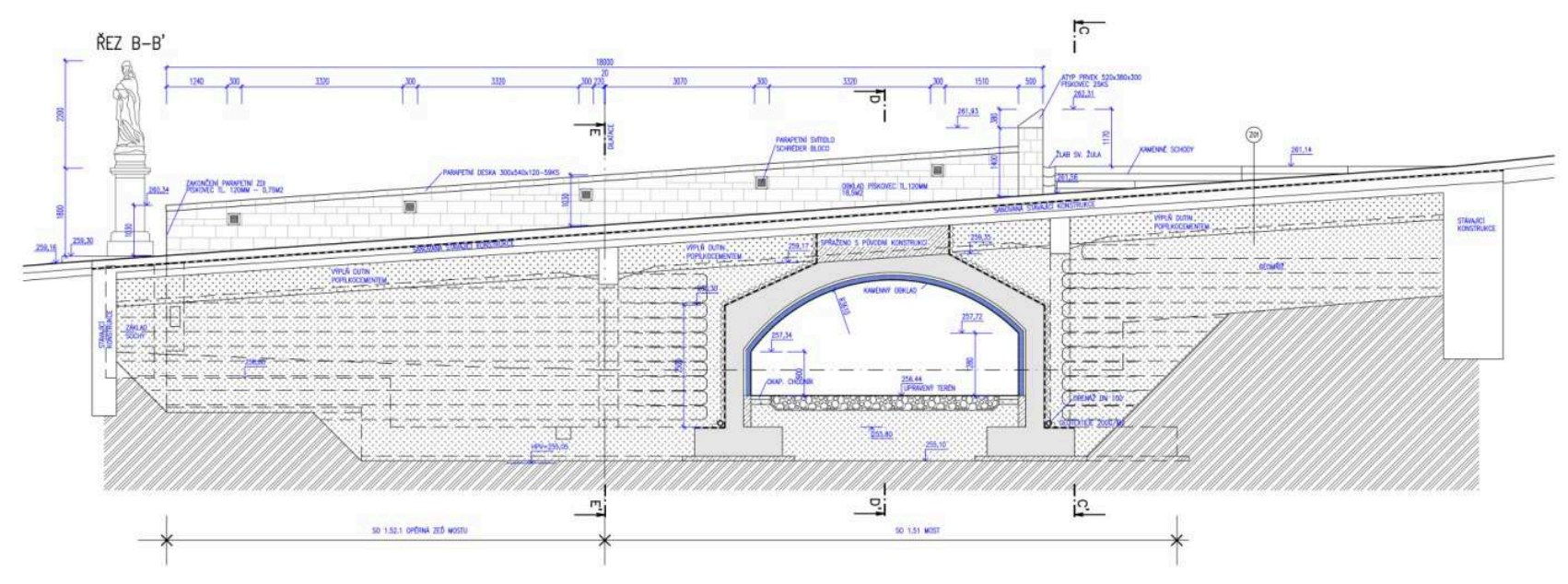

Fig. 5 - Construction cut (Jan Mrzilek, 2012)

\section{Supporting walls of the bridge}

The angled supporting wall forms a parallel (longitudinal) wing of the bridge $U$ Brodu. This wall is separated from the bridge by dilatation. The classical angled wall is founded on the flat base plate with a down flow upper surface, which corresponds to the static operation and allows water to run off. A cession of the foundation before facing the concrete wall is adapted for the foundation block stone cladding. The stone cladding is anchored to the concrete with a grip and steel fasteners embedded in the masonry joints. A stone railing is built on the crown wall. Banister rails are made of stone slabs. The longitudinal slope of the crown wall corresponds to the slope pavement, 7.9\%. A cable duct with a protector diameter of DN100mm connected to the cable chamber is hidden in the sidewalk of the bridge. The reverse part of the wall is insulated with a double epoxy-asphalt coating protected by a suspended drainage mattress, Enkadrain. This mattress prevents the impoundment of water behind the wall. Water is pumped through the mattress into the drainage system of the bridge and then into sewer B. At the free end of the wall a foundation for placing the statue of St. Anthony of Padua is separately located [4].

Materials: concrete C 30/37 XF2, concrete reinforcement R 10 505, stone facing - sandstone.

\section{Supporting walls of the bastion}

The corner facing wall creates a bastion following to the bridge $U$ Brodu. Part of the wall can be characterized as an inclined wing of the bridge. The classical wall is founded in two levels on foundation boards. The slant of the wall leading along the dry creek and following part of the slants situated along the ramparts are founded in the lower level corresponding to the foundation of the bridge. The foundation before the facing concrete wall was prepared for blocks of stone cladding. The stone cladding is anchored to the concrete with anchors and steel fasteners embedded in the masonry joints. On the crown wall there is a stone railing. Banister rails are made of stone elements unilaterally tapering upward, thereby creating an aesthetic impression of a bastion. The space on the bastion is modified into the small inclination. The pavement of Vinarickeho Street lies at a longitudinal gradient of $7.9 \%$. The bastion area in the upper part is connected directly to the pavement in the lower part by a set of small stairs. The inside wall is insulated with a double epoxyasphalt coating protected by a suspended drainage mattress Enkadrain. This mattress prevents water leakage behind the wall. The water is drained just above the water level in the pond, where it joins a perforated drainage pipe which enters into the drainage system of the dry creek [4].

Materials: concrete C 30/37 XF2, concrete reinforcement R 10 505, stone facing - sandstone. 


\section{Landscaping space at the bridge}

The space is defined by the current line of the town walls, bridge construction in Vinarickeho Street and the bank of the water tank. In the past, the space under the walls served as a moat, but the moat has not been preserved hitherto. The terrain slopes towards to the original bridge. The entire land area is covered in grass [5].

The landscaping design is based on the total illusion of a dry creek bed below the town walls and reminiscent of the original moat. The depth of the creek bed was chosen so that the designed construction of the bridge with the bastion stands out. Landscaping design around the bridge includes a possible future use of space under the walls of the promenade [5].

Initially the excavation was done by machine because of the scale the project, but the final clearing of the pit was done manually. After shaping the pit bottom of the dry creek bed, a layer of geotextile was installed to ensure the separation of the final terrain and the gravel fill of the channel. Diverse river stones with a diameter of $63-250 \mathrm{~mm}$ with rounded and sharp edges supplemented by boulders with a diameter of 0.6 to $1.2 \mathrm{~m}$ in several places were used to fill the creek bed. The landscaping design called for the areas of the slopes and the outside surface of the dry creek to be covered with grass. In order to promote the growth of grass upon the slopes, the sowing areas were reinforced with geogrid. The drainage of the area of dry creek was constructed using a drainage absorbing element with a safety overflow to the sewer [5].

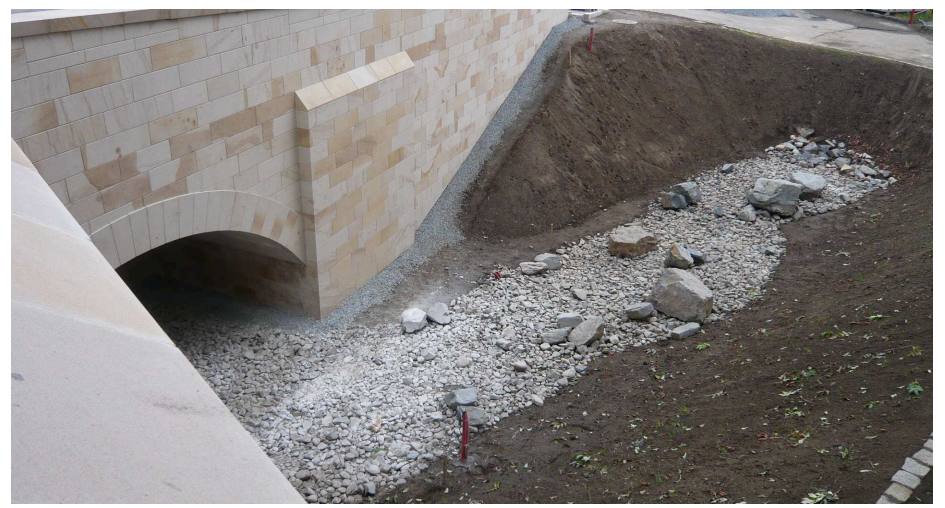

Fig. 6 - Dry creek bed, the vegetation has not grown yet (photo author, 2011)

\section{Road and paved areas}

Vinarickeho Street is designed as a two-lane, two-way road with a width of $6.6 \mathrm{~m}$ (connection to the existing unfinished part of Vinarickeho Street) to 8.1 meters (extending roads to improve the entrance from the street $U$ Brodu to Havirska Street. Most of the road is $7.0 \mathrm{~m}$ wide. On both sides of the street is a sidewalk, the width was modified in regard to a new course of curbs along the reconstructed road. The longitudinal and transverse slope of the surface is based on the morphology of the existing terrain, height connection to the current level of the street and the entries into existing buildings. The longitudinal inclinations on all the roads and paved areas do not exceed $7.2 \%$. The cross slope of the road is designed especially in regard to the course of the existing underground cable duct variable - one-sided or roof-shaped in $2.5 \%$. Due to the design speed was not designed tilt in the direction curves. Transverse inclinations pavements are designed in $2 \%$ basic inclination to towards the road. The streets are separated from the greenery and sidewalks by stone curbs $300 \times 250 \mathrm{~mm}$, placed in a concrete bed with side supports and a foot tap 0.10-0.15m. Part of the paved surfaces is a stone staircase, aligning the longitudinal pavement inclination and flat surface of the bastion at the top. The width of the step is $0.3 \mathrm{~m}$, and the height variable. The road surface is designed from cobblestones, the main pattern used is of mosaic pavements with the pattern called frame with a lady, or sheet pile paving or paving with a nature pattern. Drainage of the paved areas of roads and pavements is provided by longitudinal and transverse inclinations into 
the storm sewer - street inlets and drainage line elements. In the road surfaces and pavements remained sections of the wall of the Prague Gate which are made of natural stone [6].

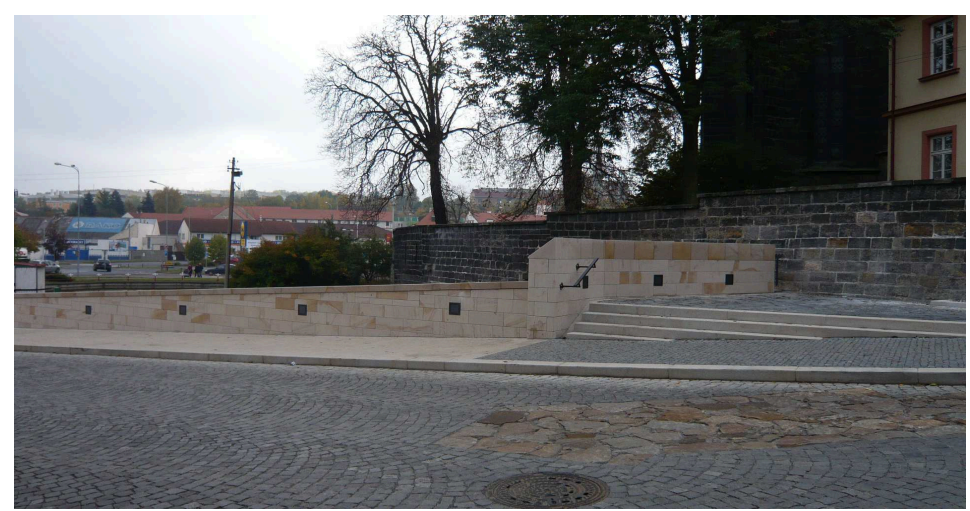

Fig. 7 - Reminder the bastion and the Prague gates in detail of paving on the road (photo author, 2011)

\section{Engineering networks}

In the street profiles of the area, virtually all types of utilities such as: sewers, water pipe system, gas (medium pressure and low pressure), power supply and power distribution network (highvoltage underground $22 \mathrm{kV}$, low-voltage $0.4 \mathrm{kV}$ - overhead, low-voltage $0.4 \mathrm{kV}$ - underground), cable of public lighting, underground cable duct routes with concrete chambers, other communication cables were to be found. Spatially resolving and coordinating all the stored networks in a complicated street profile was the most difficult task of the entire process of the construction. The most interesting task was complete removal of existing sewerage structures and their renewal so that the flow of wastewater was not interrupted [7].

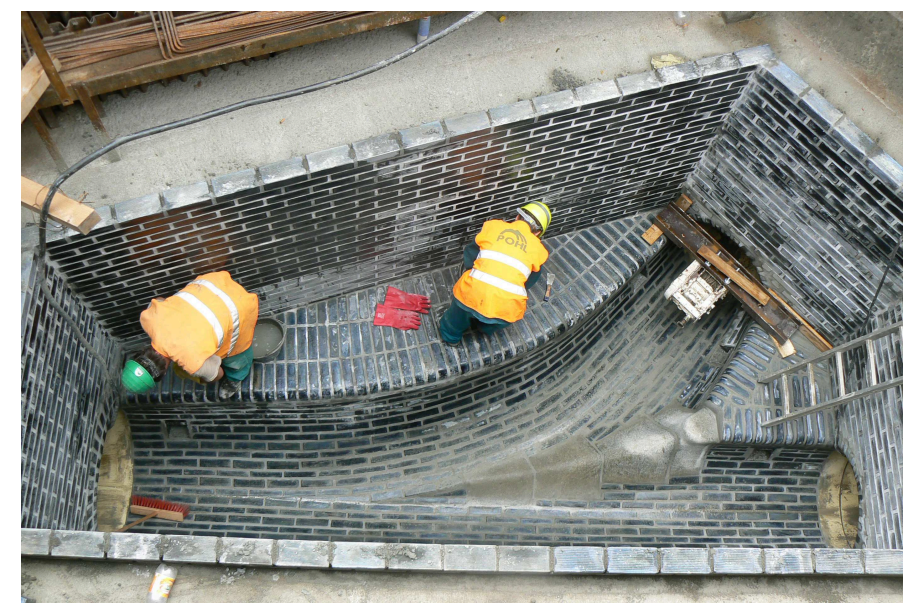

Fig. 8 - Converging chamber of sewer (photo Jan Mrzilek, 2011)

\section{Construction}

Construction started in November 2010 and lasted one year. POHL CZ, Inc. from Roztoky nearby Prague carried out the work. Professor Jaroslav Sykora put together a project team from graduates from the Faculty of Civil Engineering CTU in Prague. The members of realisation team were Ing. Jan Mrzílek, Ing. Ales Barton, Ing. Pavel Gärtner, Ing. Jan Stojka. Archaeological Survey led Mgr. Jiri Unger of the Archaeological Institute of the Academy of Sciences of Czech Republic in Prague. Academic sculptor Jan Tursky was restorer of the statue of St. Anthony of Padua. The main site manager was Ing. Karel Biskup. The cost of the construction was 30,106,819 kc without VAT (approximately 1,505,000,USD). Various technologies and crafts were combined, part of the sewers was excavated by mining method, while simultaneously archaeological rescue work was 
conducted and at the same time it was necessary to statically ensure the existing objects so that the construction process could not damage them. Due to the fact that the work was done on the main access road to the town centre, it was necessary to carry out unpleasant traffic restrictions.

\section{Summary}

The architectural part of the overall project revitalization of the historic centre of the town Slany was processed by team of architects, whose research is focused on various aspects of the historical urban and rural space. Work on this project meant especially for members of the architectural team the extraordinary opportunity to apply the principles set out in theory in a real project.

The revitalization of the lower part of Vinarickeho Street in Slany (Central Bohemia, Czech Republic) represents the first completed section of an extensive project to revitalize the historic centre of the town. It is a team work of architectural, engineering, craftsman artists, and other professions that join together to make the entry into the historic part of town gained a representative framework. Under an elegantly stitched coat of a relatively small section of the surface, complicated engineering works which solved the arrangement of twenty-two networks trustees, where are waste pipes with flow about tons of wastewater per second are hidden and also hid in the remains of medieval fortifications. Although this is a project of smaller scope, thanks to its complexity, sensitive approach and craftsmanship it brought the creators the price Construction of the Year 2012 in the Central Bohemia region and advanced to the second round in the competition Construction of the Year 2012 in Czech Republic.

\section{References}

[1] J. Sykora, J. Pospisil, P. Novotna, J. Novotny, J. Mrzilek, Z. Peskova, J. Steflicek, K. Hronovska, P. Gartner, Revitalization of the historic core of the town Slany - 1 Surveys and analyzes, architectural studies, October 2006, http://www.meuslany.cz/cs/rozvoj-mesta/revitalizacehistorickeho-jadra/architektonicka-studie/rozbory-a-pruzkumy/

[2] J. Unger, Report on the archaeological research and excavations in the Vinarickeho Street, Institute of Archaeology, Academy of Sciences in Czech Republic, 2011.

[3] J. Sykora, J. Pospisil, P. Novotna, J. Novotny, J. Mrzilek, Z. Peskova, J. Steflicek, K. Hronovska, P. Gartner, Revitalization of the historic core of the town Slany - 3 Design of adjustments in the Vinarickeho Street, architectural studies, December 2006, http://www.meuslany.cz/cs/rozvoj-mesta/revitalizace-historickeho-jadra/architektonickastudie/vinarickeho/

[4] J. Sykora, J. Mrzilek, Revitalization of the historic core of the town Slany - I. Construction: The Vinarického Street - The Bridge U Brodu, Construction of the bridge and side retaining walls, construction project (documentation for merged territorial and building permits), 2010-2011.

[5] J. Sykora, J. Mrzilek, Revitalization of the historic core of the town Slany - I. Construction: The Vinarického Street - The Bridge U Brodu, Landscaping space at the bridge, construction project (documentation for merged territorial and building permits), 2010-2011.

[6] J. Sykora, P. Gärtner, Revitalization of the historic core of the town Slany - I. Construction: The Vinarického Street - The Bridge U Brodu, Road and paved areas, construction project (documentation for merged territorial and building permits), 2010-2011.

[7] J. Sykora, A. Barton, Revitalization of the historic core of the town Slany - I. Construction: The Vinarického Street - The Bridge U Brodu, Water supply system and sewage systems, Changes in construction project of refurbishment The Vinarickeho Street, 2010-2011. 